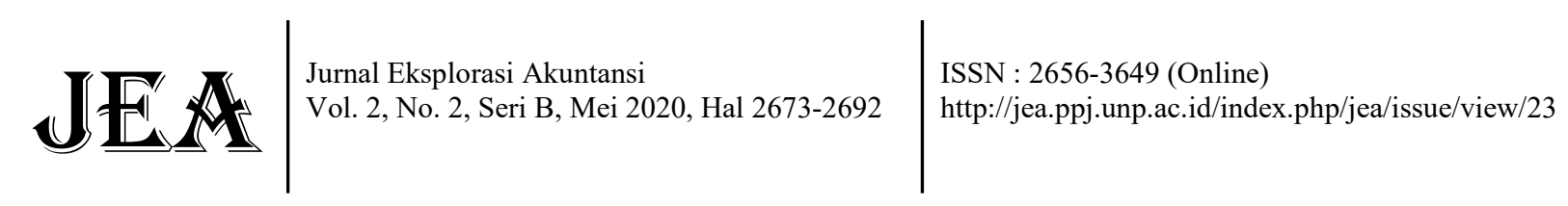

\title{
Faktor Determinan Mahasiswa Tingkat Pertama Dalam Pengambilan Keputusan Memilih Program Studi Akuntansi S1 Universitas Negeri Padang (Studi Empiris pada Mahasiswa Akuntansi S1 Angkatan 2019 Universitas Negeri Padang)
}

\author{
Charoline Cheisviyanny ${ }^{1}$, Ravi Pratama ${ }^{2}$ \\ 1Jurusan Akuntansi Fakultas Ekonomi Universitas Negeri Padang \\ ${ }^{2}$ Alumni Jurusan Akuntansi Fakultas Ekonomi Universitas Negeri Padang \\ *Korespondensi: ravipratamaa@gmail.com
}

Abstract: This study aims to analyze the factors that determine first year accounting students in choosing an undergraduate accounting study program of Universitas Negeri Padang. These factors are interests, self-potential, parental support, job opportunities, costs, university image, collective decisions, school recommendation. The population in this study was the first year accounting students of Universitas Negeri Padang. The sample is determined based on the nonprobability sampling method. The data used in this study are primary data. This study used a questionnaire to collect data. The analytical method is multiple linear regression analysis. The results showed interest, self-potential, and job opportunities have significant influences on decision making in selecting accounting study program of Universitas Negeri Padang. While parental support, fees, university assessments, collective decisions and school recommendation have no effect. Further researches are expected to explore other universities because each university has different charactetistics of students and a unique culture.

Keywords: are interests; job opportunities; self-potential; university image

How to cite (APA $6^{\text {th }}$ style):

Cheisviyanny, C. \& Pratama, R. (2020). Faktor Determinan Mahasiswa Tingkat Pertama dalam Pengambilan Keputusan Memilih Program Studi Akuntansi S1 Universitas Negeri Padang (Studi Empiris pada Mahasiswa Akuntansi S1 Angkatan 2019 Universitas Negeri Padang). Jurnal Eksplorasi Akuntansi. 2(2), Seri B, 2673-2692.

\section{PENDAHULUAN}

Manusia pada umumnya membutuhkan pendidikan yang merupakan sarana belajar untuk menggapai cita-cita yang diinginkan. Semakin tinggi tingkat pendidikan seseorang maka peluang untuk menggapai cita-cita dan keberhasilan semakin besar. Hal ini tidak dapat dipungkiri karena dengan belajar dapat mengasah kemampuan pola berpikir, kemampuan menganalisis, cara berkomunikasi yang baik, dan nalar.

Untuk mencapai keberhasilan dalam menempuh pendidikan dibutuhkan motivasi belajar yang tinggi secara berkesinambungan serta tidak mudah putus asa. Berdasarkan Undang-Undang Republik Indonesia No 20 Tahun 2003 tentang Sistem Pendidikan Nasional, pendidikan adalah 
usaha sadar dan terencana untuk mewujudkan suasana belajar dan proses pembelajaran agar peserta didik secara aktif mengembangkan potensi dirinya untuk memiliki kekuatan spiritual keagamaan, pengendalian diri, kepribadian, kecerdasan, akhlak mulia, serta keterampilan yang diperlukan dirinya, masyarakat, bangsa dan negara. Puncak dari pendidikan yang dimulai dari jenjang pendidikan dasar, menengah pertama dan sekolah menengah atas adalah di perguruan tinggi.

Sulistyawati, dkk (2017) dalam hasil penelitiannya menunjukkan bahwa minat,potensi diri, dukungan orang tua, dan peluang pekerjaan berpengaruh positif terhadap proses pengambilan keputusan terhadap jurusan akuntansi. Berdasarkan saran yang diambil dari penelitian sebelumnya dan yang akan membedakan penelitian ini dari penelitian sebelumnya yaitu adanya penambahan variabel baru yaitu faktor rekomendasi dari sekolah. Yang mana berdasarkan pengalaman peneliti sebagai siswa sekolah menengah atas dan pengalaman teman-teman dari peneliti berkemungkinan bahwa rekomendasi sekolah juga memiliki pengaruh terhadap penentuan pengambilan keputusan dalam memilih program studi. Hal ini dikarenakan karena beberapa inidikator sekolah merekomendasikan sebuah pilihan program studi kepada siswa salah satunya yaitu agar meningkatkan citra dari suatu sekolah disebabkan karena siswa yang telah lulus tersebut merupakan hasil dari proses belajar disekolah yang bersangkutan dan sudah menciptakan output dalam bentuk siswa-siswi terbaik dan telah diterima oleh universitas ternama dengan program studi akuntansi berakreditasi A.

Berdasarkan uraian diatas, penulis tertarik untuk melakukan penelitian dengan judul

"Faktor Determinan Mahasiswa Tingkat Pertama dalam Pengambilan Keputusan Memilih Program Studi Akuntansi S1 Universitas Negeri Padang" (Studi Empiris pada Mahasiswa Akuntansi S1 Angkatan 2019 Universitas Negeri Padang).

\section{REVIU LITERATUR DAN PENGEMBANGAN HIPOTESIS \\ Teori Pengambilan Keputusan (Theory of Decision Making)}

George R Terry (1986) mengatakan bahwa kebijakan adalah suatu tindakan yang mengarah pada tujuan tertentu yang dilakukan oleh seorang aktor atau beberapa aktor berkenaan dengan suatu masalah. Tindakan para aktor kebijakan dapat berupa pengambilan keputusan yang biasanya bukan merupakan keputusan tunggal, artinya kebijakan diambil dengan cara mengambil beberapa keputusan yang saling terkait dengan masalah yang ada. Pengambilan keputusan dapat diartikan sebagai pemilihan alternatif terbaik dari beberapa pilihan alternatif yang tersedia.

\section{Teori Behavioral (Krumboltz)}

Dalam Munandir (1996:97) teori Krumboltz berdasarkan teori pembelajaran sosial lebih memfokuskan pada proses pembelajaran yang mengarahkan pada keyakinan dalam minat dalam diri serta bagaimana hal ini mempengaruhi proses pengambilan keputusan. Munculnya teori ini berdasarkan teori belajar sosial berkembang dari teori behaviorisme dan teori tentang penguatan. Menurut Munandir (1996:97) teori Krumboltz menganggap penting pribadi dan lingkungan sebagai faktor yang menentukan keputusan seseorang tentang karir.

\section{Teori Pengamatan Terpadu (Mixed Scanning Theory)}

Model pengamatan terpadu menurut Etzioni (1968) akan memungkinkan para pembuat keputusan menggunakan teori rasional komprehensif dan teori inkremental pada situasi yang berbeda-beda. Model pengamatan terpadu ini pada hakikatnya merupakan pendekatan kompromi yang menggabungkan pemanfaatan model rasional komprehensif dan model inkremental dalam 
proses pengambilan keputusan.

\section{Pengembangan Hipotesis}

a. Minat dan Pemilihan Program Studi

Menurut Eysenck, 1953 (dalam Sovia, 2007: 22) minat sebagai sikap positif terhadap obyek atau sekelompok obyek yang membuat seseorang menjadi tertarik terhadap objek tersebut. Menurut Crow, 1950 (dalam Sovia, 2007: 22) minat berhubungan dengan "motivating force" yang menyebabkan seseorang memperhatikan sesuatu, dapat berupa orang, obyek, atau aktifitas atau dapat berupa pengalaman afektif yang telah distimulasi oleh aktivitas itu sendiri.

H1: Minat berpengaruh terhadap pengambilan keputusan mahasiswa dalam memilih Program Studi Akuntansi

\section{b. Potensi Diri dan Pemilihan Program Studi}

Dalam Yumnah (2016:25) Menyatakan potensi diri ialah kemampuan yang dimiliki setiap individu yang mempunyai kemungkinan untuk dikembangkan dalam berprestasi atas kemampuan yang terpendam pada diri seseorang. Sri Habsari (2005: 2) menyatakan bahwa potensi diri adalah kemampuan dan kekuatan yang dimiliki oleh seseorang baik fisik maupun mental dan mempunyai kemungkinan untuk dikembangkan bila dilatih ditunjang dengan sarana yang baik.

Ciri orang yang memahami potensi dirinya bisa diukur atau dilihat dalam sikap dan perilakunya sehari-hari dalam kehidupan keluarga, sekolah dan masyarakat. Menurut LaRose (Sugiharso dkk,2009:126-127) menyebutkan bahwa orang yang berpotensi memiliki inidkator sebagai berikut; Suka belajar dan mau melihat kekurangan dirinya, memiliki sikap yang luwes, berani melakukan perubahan untuk perbaikan.

H2: Potensi diri berpengaruh terhadap pengambilan keputusan mahasiswa dalam memilih Program Studi Akuntansi

c. Dukungan Orang Tuadan Pemilihan Program Studi

Sobur (2003) menyatakan bahwa indikator dukungan orangtua sebagai penentu keberhasilan siswa terdiri dari kondisi ekonomi keluarga

H3: Dukungan Orang Tua berpengaruh terhadap pengambilan keputusan mahasiswa dalam memilih Program Studi Akuntansi

\section{d. Peluang Pekerjaan dan Pemilihan Program Studi}

Swasono dan Sulistyaningsih (1993), memberi pengertian kesempatan kerja adalah termasuk lapangan pekerjaan yang sudah diduduki (employment) dan masih lowong (vacancy). Dari lapangan pekerjaan yang masih lowong tersebut timbul kemudian kebutuhan tenaga kerja yang datang misalnya dari perusahaan swasta atau BUMN dan departemen-departemen pemerintah. Indikator-indikator yang mempengaruhi kesempatan kerja menurut Bambang, (2008:66) antara lain sebagai berikut; Usia tenaga kerja, tingkat pendidikan, pengetahuan, keterampilan dan keahlian.

H4: Peluang pekerjaan berpengaruh terhadap pengambilan keputusan mahasiswa dalam memilih Program Studi Akuntansi

e. Biaya dan Pemilihan Program Studi 
Menurut Lupioyadi dan Hamdani dalam Hadiprasetyo dan Endra (2014), perguruan tinggi menggunakan penentuan biaya perkuliahan yang berbeda untuk tiap mahasiswa dan program, antara lain; Berdasarkan program studi, contoh: ekonomi, teknik, bahasa, hokum. Berdasarkan tingkatan mahasiswa, contoh: Mahasiswa S1 berbeda dengan pascasarjana, dimana biaya untuk pascasarjana lebih mahal. Dalam penelitian yang telah dilakukan oleh Hadipraestyo dan Endra (2014), bahwa indikator biaya pendidikan antara lain; Biaya registrasi pendidikan, Biaya beban sks per semester

H5: Biaya berpengaruh terhadap pengambilan keputusan mahasiswa dalam memilih Program Studi Akuntansi.

\section{f. Citra Universitas dan Pemilihan Program Studi}

Menurut Deephouse dalam Wibowo (2009) citra juga sering didefenisikan sebagai keunggulan kompetitif terpenting yang dimiliki oleh perusahaan. Hariawan, 2015 (dalam Kusuma 2016: 55) mengatakan bahwa citra adalah persepsi keseluruhan dari suatu perusahaan, berhubungan dengan apa yang mungkin seharusnya didapatkan ketika pelanggan membeli produk atau menggunakan layanan dari perusahaan. Indikator-indikator citra universitas yang dapat dipakai dalam penelitian ini antara lain berdasarkan penelitian yang dilakukan Andreassen dalam Subkan (2006); Kompetensi perguruan tinggi, keunggulan perguruan tinggi

H6: Citra universitas berpengaruh terhadap pengambilan keputusan mahasiswa dalam memilih Program Studi Akuntansi

\section{g. Keputusan Kolektif dan Pemilihan Program Studi}

Assael, 1992 (dalam Gunawan, 2004 :41) menemukan bahwa pembuatan keputusan bersama sangat memunginkan pada situasi ketika tingkat resiko yang dirasakan dalam pembelian tinggi, ketika ada keputusan pembelian penting untuk keluarga. Berdasarkan penelitian Schutte \& Ciarlante, 1998 (dalam Sovia 2007: 24) perilaku orang Asia cenderung mempertimbangkan masyarakat bersama/kelompok bukan secara individu.

H7: Keputusan Kolektif berpengaruh terhadap pengambilan keputusan mahasiswa dalam memilih Program Studi Akuntansi

h. Rekomendasi Dari Sekolah dan Pemilihan Program Studi

Dalam literatur, rekomendasi dikategorikan sebagai salah satu kajian tentang pengaruh faktor personal atau word of mouth research (Senecal \& Nantel, 2004). Andreasen (1968, dalam Senecal dan Nantel, 2004) mengkategorikan jenis-jenis rekomendasi kedalam; Rekomendasi yang bersifat enganjurkan dan tidak ditujukan kepada orang tertentu (impersonal advocat). Contoh: Rekomendasi yang diberikan oleh media massa, rekomendasi yang diberikan sebuah lembaga independen dan tidak ditujukan kepada orang tertentu (impersonal independent). Contoh: rekomendasi dari sekolah kepada siswa-siswa nya.

H8: Rekomendasi dari sekolah berpengaruh terhadap pengambilan keputusan mahasiswa dalam memilih Program Studi Akuntansi.

\section{Kerangka Konseptual}




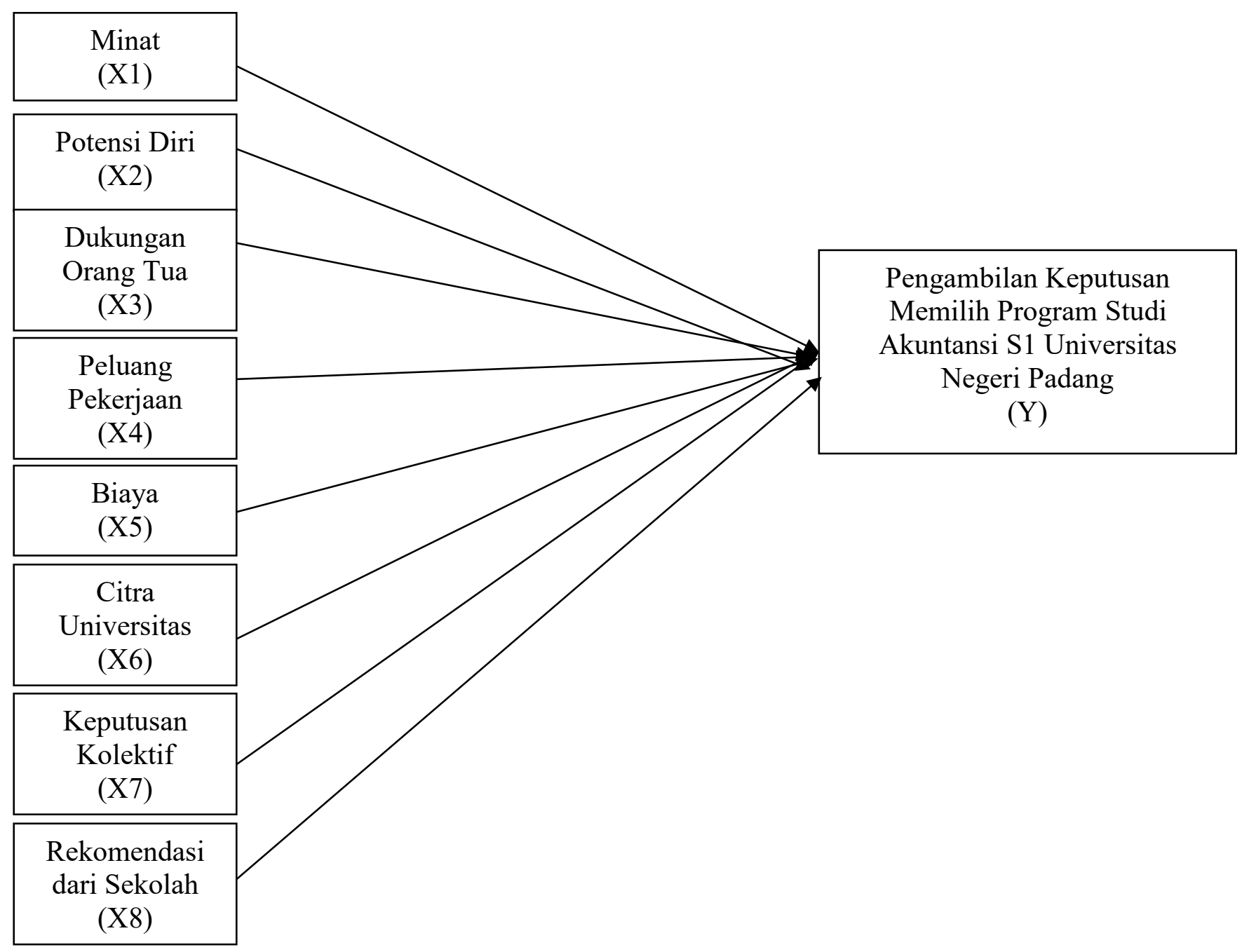

Gambar 1. Kerangka Konseptual

\section{METODE PENELITIAN}

\section{Jenis Penelitian}

Berdasarkan rumusan masalah dan tujuan penelitian yang telah dijelaskan pada bab terdahulu, maka jenis penelitian ini dikelompokan pada penelitian asosiasi kausatif (causative). Dimana penelitian ini bertujuan untuk melihat seberapa jauh variabel bebas (independen) mempengaruhi variabel (dependen) terikat. Penelitian ini berusaha menjelaskan pengaruh Minat $\left(\mathrm{X}_{1}\right)$, Potensi Diri $\left(\mathrm{X}_{2}\right)$, Dukungan Orang tua $\left(\mathrm{X}_{3}\right)$, Peluang Pekerjaan $\left(\mathrm{X}_{4}\right)$, Biaya $\left(\mathrm{X}_{5}\right)$, Citra Universitas $\left(\mathrm{X}_{6}\right)$, Keputusan Kolektif $\left(\mathrm{X}_{7}\right)$, Rekomendasi Dari Sekolah $\left(\mathrm{X}_{8}\right)$ sebagai variabel independen terhadap Pengambilan Keputusan Mahasiswa Memilih Program Studi Akuntansi (Y) sebagai variabel dependen.

\section{Populasi dan Sampel Penelitian}

Populasi adalah keseluruhan objek penelitian. Populasi yang digunakan dalam penelitian ini adalah mahasiswa Akuntansi Fakultas Ekonomi Angkatan 2019 Universitas Negeri Padang. Pengambilan sampel dilakukan dengan purposive sampling, artinya sampel dipilih berdasarkan 
pertimbangan subjektif penelitian dimana persyaratan yang dibuat sebagai kriteria harus dipenuhi sebagai sampel.

Kriteria yang ditentukan dalam purposive sampling adalah mahasiswa Akuntansi Fakultas Ekonomi Angkatan 2019 Universitas Negeri Padang yang telah lulus dari Sekolah Menengah Atas (SMA) jurusan IPA atau IPS dan Sekolah Menengah Kejuruah (SMK). Alasan pemilihan kriteria sampel ini adalah :

a. Mereka telah memiliki rencana atau pemikiran mengenai alternatif program studi apa saja yang akan dipilih, sebelum akhirnya memilih program studi akuntansi.

b. Diharapakan telah memiliki pengetahuan tentang dasar-dasar akuntansi sehingga dapat memberikan jawaban sesuai minat dan potensi diri mereka.

c. Jumlah sampel Mahasiswa Akuntansi Fakultas Ekonomi Angkatan 2019 Universitas Negeri Padang yaitu sebanyak 144 orang

\section{Jenis dan Sumber Data}

a. Jenis Data

Dilihat dari cara memperolehnya data ini digolongkan pada data subjek. Data subjek (self report data) adalah jenis data penelitian yang berupa opini, sikap, pengalaman/karakteristik dari seorang/ sekelompok orang yang menjadi subjek penelitian (responden).

b. Sumber Data

Data yang digunakan adalah data primer yaitu data yang berasal dari kuesioner. Data primer adalah data yang secara langsung bersumber dari responden tanpa ada perantara, dalam hal ini adalah dari jawaban atas pertanyaan-pertanyaan yang ada dalam kuesioner. Data primer yang dihasilkan dalam penelitian ini adalah merupakan hasil dari tanggapan responden terhadap variabel-variabel penelitian yang akan diuji.

\section{Metode Pengumpulan Data}

Teknik pengumpulan data dalam penulisan proposal penelitian ini, digunakan dua cara penelitian:

a. Studi kepustakaan

Dilakukan untuk mengumpulkan data acuan, literatur-literatur dan buku-buku yang relevan untuk mendapatkan landasan teoritis yang akan digunakan sebagai bahan referensi dalam penelitian penulis.

b. Penelitian lapangan

Data dikumpulkan menggunakan teknik kuesioner personal (personally administrated questionnaires). Responden diminta untuk mengisi kuesioner.

\section{Teknik Analisis Data}

a. Uji Asumsi Klasik

1)Uji Normalitas

Uji normalitas residual dilakukan dengan menggunakan Kolmogorov-Smirnov test dengan taraf signifikan 5\%. Dasar pengambilan keputusan nilai Sig $\geq 0,05$ maka dikatakan berdistribusi normal. Jika nilai Sig $<0,05$ maka dikatakan berdistribusi tidak normal.

2) Uji heterokedastisitas

Uji heterokedastisitas bertujuan untuk menguji apakah dalam model regresi terjadi ketidaksamaan varian dari residual satu pengamatan ke pengamatan yang lain (nilai errornya). 
Menguji ada atau tidaknya heteroskedastisitas maka penelitian ini melihat grafik scatterplots antara nilai prediksi terikat (dependen) yaitu ZPRED (Standardized Predicted Value) dengan residualnya SRESID (Standardized Residual). Jika ada pola tertentu, seperti titik yang ada membentuk pola tertentu yang teratur (bergelomang, melebar kemudian menyempit), maka mengindikasi telah terjadi heteroskedasitas. Jika tidak ada pola yang jelas, serta titik menyebar di atas dan di bawah angka 0 pada sumbu Y, maka tidak terjadi heteroskedasitas.

3) Uji Multikolenearitas

Uji multikolinearitas bertujuan untuk menguji apakah model regresi ditemukan adanya korelasi antar variabel bebas atau indepenen. Pengujian ini dilakukan untuk melihat ada tidaknya hubungan linear antara variabel bebas yang dilakukan dengan menggunakan Variance Inflation Factor (VIF) dan tolerance value. Tolerance mengukur variabilitas variabel independenyang terpilih yang tidak dijelaskan oleh variabel independen lainnya, jadi nilai tolerance yang rendah samadengan nilai VIF yang tinggi. Nilai yang umum digunakan adalah tolerance value $>0.10$ atau samadengan nilai VIF $<10$. Jika tolerance value dibawah 0.10 atau nilai VIF diatas 10 , maka terjadi multikolinearitas (Ghozalli, 2011).

b. Teknik Analisis Data

1) Analisis Statistik Deskriptif

Analisis statistik deskriptif digunakan untuk memberikan penjelasan dan gambaran umum demografi responden penelitian dan deskripsi mengenai variabel-variabel penelitian.

a) Verifikasi data

Verifikasi data yaitu memeriksa kembali kuesioner yang telah diisi oleh responden untuk memastikan apakah pertanyaan sudah diisi oleh responden.

b) Menghitung nilai jawaban

i. Menghitung frekuensi dari jawaban yang diberikan responden atas setiap item pertanyaan yang diajukan.

ii. Menghitung rata-rata skor total item

iii. Menghitung nilai rata-rata jawaban responden dengan menggunakan rumus:

$$
\text { Mean }=\frac{\sum_{h=1}^{n} x_{i}}{n}
$$

Dimana :

$\mathrm{x}_{\mathrm{i}}=$ Skor Total

$\mathrm{n}=$ Jumlah Responden

iv. Menghitung nilai TCR masing-masing kategori jawaban dari deskriptif variabel dengan menggunakan rumus:

$$
T C R=\frac{R_{s}}{n} \times 100
$$

Dimana :

TCR = Tingkat Capaian Responden

$\mathrm{R}_{\mathrm{s}} \quad=$ Rata-rata Skor Jawaban Responden

$\mathrm{N}=$ Nilai Skor Jawaban 
2) Uji Kelayaan Model

a) Uji F (F-test)

Uji statistik F pada dasarnya menunjukkan apakah semua variabel bebas dimasukkan dalam model mempunyai pengaruh secara bersama-sama terhadap variabel terikat. Nilai F statistik F dihitung dari formula sebagai berikut:

$$
\mathrm{F}=\frac{R^{2} / k}{\left(1-R^{2}\right) /(n-k-1)} \quad \text { (Irianto, 2004:207) }
$$

Jika $\mathrm{F}_{\text {hitung }}>\mathrm{F}_{\text {tabel}}$, maka $\mathrm{H}_{0}$ ditolak

Jika $\mathrm{F}_{\text {hitung }}<\mathrm{F}_{\text {tabel, }}$, maka $\mathrm{H}_{0}$ diterima

Dengan tingkat kepercayaan $(\alpha)$ untuk pengujian hipotesis adalah $95 \%$ atau $(\alpha)=0.05$.

b)Uji Regresi Berganda

Metode statistik yang digunakan untuk menguji hipotesis adalah regresi berganda (multiple regression analysis). Uji regresi berganda bertujuan untuk mengetahui pengaruh variabel independen terhadap variabel dependen maka digunakan model regresi berganda dengan persamaan sebagai berikut :

$$
\mathrm{Y}=\alpha+\beta 1 \mathrm{X} 1+\beta 2 \mathrm{X} 2+\beta 3 \mathrm{X} 3+\beta 4 \mathrm{X} 4+\beta 5 \mathrm{X} 5+\beta 6 \mathrm{X} 6+\beta 7 \mathrm{X} 7+\beta 8 \mathrm{X} 8 \mathrm{C}+\mathrm{e}
$$

$$
\begin{aligned}
\text { Keterangan : } \mathrm{Y} & =\text { Pengambilan Keputusan } \\
\alpha & =\text { Koefisien Intercept (konstanta) } \\
\beta & =\text { Koefisian Regresi } \\
\mathrm{X}_{1} & =\text { Minat } \\
\mathrm{X}_{2} & =\text { Potensi Diri } \\
\mathrm{X}_{3} & =\text { Dukungan Orang Tua } \\
& \mathrm{X}_{4} \quad=\text { Peluang Pekerjaan } \\
& \mathrm{X}_{5} \quad \text { = Biaya } \\
& \mathrm{X}_{6} \quad \text { = Citra Universitas } \\
& \mathrm{X}_{7} \quad \text { Keputusan Klektif } \\
\mathrm{X}_{8} & =\text { Rekomendasi Sekolah } \\
\mathrm{e} & =\text { Error }
\end{aligned}
$$

c) Uji Koefisien Determinasi $\left(\mathrm{R}^{2}\right)$

Untuk mengetahui kontribusi dari variabel bebas terhadap variabel terikat dilihat dari adjusted $R$ square-nya, pemilihan nilai adjusted $R$ square karena penelitian ini menggunakan analisis regresi berganda dengan jumlah variabel lebih dari satu. Koefisien determinasi $\left(R^{2}\right)$ pada intinya mengukur seberapa jauh kemampuan model dalam menerangkan variasi variabel terikat. Pengujian uji Koefisien Determinasi $\left(\mathrm{R}^{2}\right)$ menggunakan program SPSS versi 21.

\section{d) Uji T (T-Test)}

Uji statistik t pada dasarnya menunjukkan seberapa jauh pengaruh satu variabel penjelas secara individual dalam menerangkan variasi variabel terikat. Statistik $t$ dihitung dari formula sebagai berikut: 


$$
t_{k}=\frac{b_{k}}{S_{b k}} \quad \text { (Irianto, 2004:204) }
$$

Jika $t_{\text {hitung }} \geq \mathrm{t}_{\text {tabel}}$, maka $\mathrm{H}_{0}$ ditolak

Jika $\mathrm{t}_{\text {hitung }}<\mathrm{t}_{\text {tabel, }}$, maka $\mathrm{H}_{0}$ diterima

Dengan tingkat kepercayaan $(\alpha)$ untuk pengujian hipotesis adalah 95\% atau $(\alpha)=0.05$.

\section{HASIL DAN PEMBAHASAN Hasil Penelitian}

Jumlah sasaran sampel dalam penelitian ini adalah Fakultas Ekonomi Program Studi Akuntansi Angkatan 2019 Universitas Negeri Padang. Seluruh sampel dalam penelitian ini yaitu mahasiswa akuntansi tingkat awal dari Fakultas Ekonomi Universitas Negeri Padang sejumlah 144 responden dan menyebar kuisioner untuk mengolah data kuesioner. Kuisioner ini disebarkan sejak tanggal 4 Februari sampai dengan tanggal 6 Maret 2020. Kuesioner yang telah kembali dan dapat diolah sebanyak 70 responden seluruh angkatan 2019 program studi Akuntansi Fakultas Ekonomi Universitas Negeri Padang yang berhubungan dengan pengambilan keputusan dalam memilih program studi akuntansi Universitas Negeri Padang. Berikut disajikan jumlah responden dan nama-nama Mahasiswa angkatan 2019 Program Studi Akuntansi Universitas Negeri Padang yang menjadi objek penelitian ini. Berikut disajikan jumlah responden dalam bentuk tabel yang menjadi objek penelitian ini.

\section{Tabel 1}

\section{Jumlah Responden Mahasiswa Akuntansi S1 angkatan 2019 Fakultas Ekonomi} Universitas Negeri Padang

\begin{tabular}{ccc}
\hline Jenis Kelamin & Jumlah & Persentase (\%) \\
\hline Laki-Laki & 12 & $17,14 \%$ \\
\hline Perempuan & 58 & $82,86 \%$ \\
\hline Total Jumlah & 70 & $100 \%$ \\
\hline
\end{tabular}

Sumber : Tata Usaha Program Studi Akunsi S1 Fakultas Ekonomi Universitas Negeri Padang

\section{Uji Asumsi Klasik}

Uji asumsi klasik digunakan untuk mendeteksi ada atau tidaknya penyimpangan asumsi klasik atau persamaan regresi linear berganda yang digunakan.Pengujian ini terdiri atas uji normalitas, uji multikolinearitas dan uji heteroskedastisitas. Berikut hasilnya akan dijelaskan satu per satu.

\section{a. Uji Normalitas}

Alat uji normalitas yang digunakan untuk menguji data yang berdistribusi normal adalah One Sample Komogorov-Smirnov (KS).Pada pengujian normalitas menggunakan uji KolmogorvSmirnov. Jika nilai signifikansi $>0,05$ maka Ho diterima (berdistribusi normal) sedangkan jika nilai signifikansi < 0,05 maka Ho ditolak (tidak berdistribusi normal) (Ghozali, 2016).

Tabel 2. Uji Normalitas

One-Sample Kolmogorov-Smirnov Test

\begin{tabular}{|c|c|c|}
\hline & & $\begin{array}{c}\text { Unstandardized } \\
\text { Residual }\end{array}$ \\
\hline $\mathrm{N}$ & & 70 \\
\hline Normal Parameters ${ }^{\mathrm{a}, \mathrm{b}}$ & Mean &, 0000000 \\
\hline
\end{tabular}




\begin{tabular}{llr}
\hline & Std. Deviation & 1,47720524 \\
\hline \multirow{2}{*}{ Most Extreme Differences } & Absolute &, 097 \\
\cline { 2 - 3 } & Positive &, 050 \\
\cline { 2 - 3 } & Negative &,- 097 \\
\hline Kolmogorov-Smirnov Z & &, 815 \\
\hline Asymp. Sig. (2-tailed) &, 519 \\
\hline
\end{tabular}

a. Test distribution is Normal.

b. Calculated from data.

Berdasarkan hasil analisis metode One Sample Kolmogorov-Smirnov pada tabel 4.110 diatas, menunjukkan bahwa nilai Kolmogorov-Smirnov adalah sebesar 0,815 dan nilai signifikan $0,519>0,05$, ini berarti bahwa data terdistribusi secara normal.

b. Uji moltikolorienitas

Multi kolonieritas bertujuan untuk menguji apakah adanya korelasi antar variabel bebas atau independent dalam model regresi. Untuk mendeteksi adanya masalah multikolonieritas dalam penelitian ini dengan menggunakan nilai Tolerance dan Variance Inflation Factor(VIF). Regresi yang terbebas dari masalah multikolonieritas apabila $V I F<10$ dan nilai Tolerance $>$ 0.10 maka data tersebut tidak Multikolonieritas (Ghozali, 2016).

\section{Tabel 3}

Uji multikolorienitas

\begin{tabular}{|c|c|c|c|c|c|c|c|c|}
\hline \multirow{2}{*}{\multicolumn{2}{|c|}{ Model }} & \multicolumn{2}{|c|}{$\begin{array}{l}\text { Unstandardized } \\
\text { Coefficients }\end{array}$} & \multirow{2}{*}{$\begin{array}{c}\text { Standardized } \\
\text { Coefficients } \\
\text { Beta }\end{array}$} & \multirow[t]{2}{*}{$\mathrm{t}$} & \multirow[t]{2}{*}{ Sig. } & \multicolumn{2}{|c|}{ Collinearity Statistics } \\
\hline & & $\mathrm{B}$ & Std. Error & & & & Tolerance & VIF \\
\hline & (Const.) & 6,557 & 2,276 & & 2,881 &, 005 & & \\
\hline & X1 &, 700 & ,105 & ,671 & 6,674 &, 000 & ,495 & 2,021 \\
\hline & $\mathrm{X} 2$ &,- 118 & ,088 &,- 144 & $-1,349$ & ,182 & ,438 & 2,282 \\
\hline & $\mathrm{X3}$ &,- 028 &, 142 &,- 017 &,- 197 & ,845 & ,661 & 1,513 \\
\hline \multirow[t]{5}{*}{1} & $\mathrm{X} 4$ &,- 005 &, 123 &,- 004 &,- 044 &, 965 &, 489 & 2,046 \\
\hline & $\mathrm{X} 5$ &,- 102 &, 066 &,- 120 & $-1,549$ & , 126 & ,840 & 1,191 \\
\hline & $\mathrm{X} 6$ & ,270 &, 118 &, 220 & 2,295 &, 025 &, 541 & 1,848 \\
\hline & $\mathrm{X7}$ &,- 064 &, 065 &,- 079 &,- 981 &, 330 & ,767 & 1,304 \\
\hline & $\mathrm{X} 8$ & ,121 & ,066 &, 173 & 1,832 & ,072 &, 562 & 1,779 \\
\hline
\end{tabular}

a. Dependent Variable: $Y$

Dari hasil output diatas, hasil perhitungan nilai tolerance setiap variabel lebih besar dari 0,10 dan nilai VIF setiap variabel kurang dari 10. Kesimpulannya maka data tersebut tidak multikolonieritas.

c. Uji Heteroskedastisitas

Uji heterokedastisitas bertujuan untuk menguji apakah dalam model regresi terjadi ketidaksamaan varian dari residual satu pengamatan ke pengamatan yang lain (nilai errornya).Dalam penelitian, pengujian heterokedastisitas dilakukan dengan melihat pola titiktitik pada grafik regeresi antara nilai prediksi variabel terikat (dependen) yaitu ZPRED (Standardized Predicted Value) dengan residualnya SRESID (Standardized Residual).Uji yang baik seharusnya tidak terjadi heterokedastisitas.Pada hasil pengolahan data didapatkan grafik regresi scatterplot sebagai berikut. 


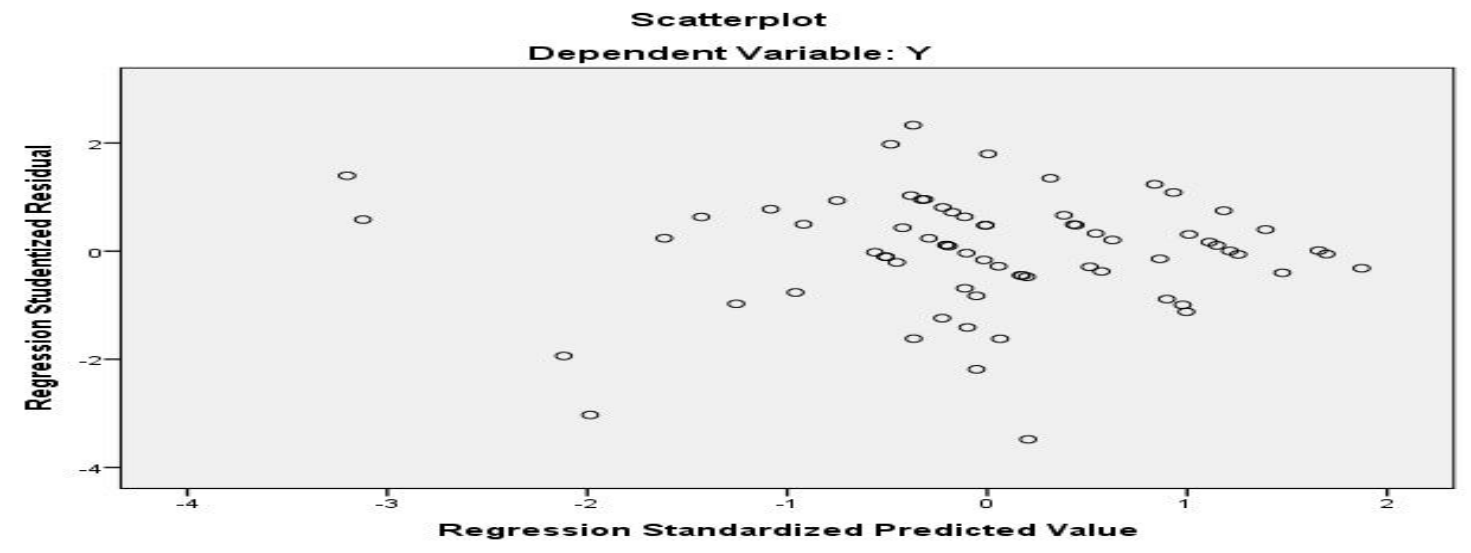

\section{Gambar 2. Uji Heteroskedastisitas}

Gambar di atas menunnjukkan tidak terdapat pola tertentu pada grafik scatterplot antara SRESID dan ZPRED dimana sumbu $\mathrm{Y}$ adalah residual (Y prediksi-Y sesungguhnya) yang telah distandardized.Jadi tidak ada pola yang jelas, serta titik menyebar di atas dan di bawah angka 0 pada sumbu Y, maka dapat disimpulkan tidak terjadi heterokedastisitas dan layak untuk diteliti.

4. Uji Kelayakan Model

a. Koefesien determinasi $\left(\mathrm{R}^{2}\right)$

Merupakan alat yang digunakan untuk mengukur seberapa jauh kemampuan model dalam menerangkan variasi variabel dependen.Nilai koefisien determinasi antara nol dan satu.Semakin nilai $\mathrm{R}^{2}$ mendekati satu maka variabel - variabel independen memberikan hampir semua informasi yang dibutuhkan untuk memprediksi variabel - variabel dependen (Ghozali, 2016). Dari hasil output diatas mennjukkan besarnya nilai Adjusted $\mathrm{R}^{2}$ adalah 0,655 atau $65,5 \%$ variabel dependen dapat dijelaskan oleh variabel independen. Sedangkan sisanya $(100 \%-65,5 \%=34,5 \%)$ dijelaskan oleh variabel lain diluar dari variable penelitian ini.

\section{Tabel 4}

\section{Uji Koefisien Determinasi}

\begin{tabular}{lccccr}
\hline Model & R & R Square & $\begin{array}{c}\text { Adjusted R } \\
\text { Square }\end{array}$ & $\begin{array}{c}\text { Std. Error of the } \\
\text { Estimate }\end{array}$ & Durbin-Watson \\
\hline 1 &, $834^{\mathrm{a}}$ &, 695 &, 655 & 1,57109 & 1,678 \\
\hline $\begin{array}{l}\text { a. Predictors: (Constant), X8, X5, X3, X7, X6, X4, X1, X2 } \\
\text { b. Dependent Variable: Y }\end{array}$
\end{tabular}

b. Uji F

\section{Tabel 5}

Uji F

\begin{tabular}{llrrrrr}
\hline Model & & Sum of Squares & df & Mean Square & F & \multicolumn{1}{c}{ Sig. } \\
\hline \multirow{3}{*}{1} & Regression & 343,718 & 8 & 42,965 & 17,407 &, $000^{\mathrm{b}}$ \\
\cline { 2 - 7 } & Residual & 150,567 & 61 & 2,468 & & \\
\cline { 2 - 7 } & Total & 494,286 & 69 & & & \\
\hline
\end{tabular}

a. Dependent Variable: Y

b. Predictors: (Constant), X8, X5, X3, X7, X6, X4, X1, X2 
Berdasarkan tabel diatas, diketahui $\mathrm{F}_{\text {hitung }}$ sebesar 17,407 $>\mathrm{F}_{\text {tabel }}$ sebesar 2,09 dengan signifikansi $0,000<0$, 05.sehingga dapat disimpulkan bahwa variabel dependen bepengaruh secara simultan terhadap variabel indpendent serta persamaan regresi yang digunakan dalam penelitian ini dapat diandalkan atau model sudah fixed.

c. Analisis regresi berganda

Tujuan dari analisis regresi linear berganda untuk mengetahui apakah variabel independen berhubungan positif atau negatif terhadap variabel dependen. Dari hasil output dibawah ini dapat dilihat persamaan regresi linear berganda seperti berikut.

Tabel 6

Analisis regresi berganda

\begin{tabular}{|c|c|c|c|c|c|c|c|c|}
\hline \multirow{2}{*}{\multicolumn{2}{|c|}{ Model }} & \multicolumn{2}{|c|}{$\begin{array}{l}\text { Unstandardized } \\
\text { Coefficients }\end{array}$} & \multirow{2}{*}{$\begin{array}{c}\text { Standardized } \\
\text { Coefficients } \\
\text { Beta } \\
\end{array}$} & \multirow[t]{2}{*}{$\mathrm{t}$} & \multirow[t]{2}{*}{ Sig. } & \multicolumn{2}{|c|}{$\begin{array}{l}\text { Collinearity } \\
\text { Statistics }\end{array}$} \\
\hline & & B & Std. Error & & & & Tolerance & VIF \\
\hline \multirow{9}{*}{1} & (Constant) & 6,557 & 2,276 & & 2,881 &, 005 & & \\
\hline & $\mathrm{X} 1$ &, 700 &, 105 & ,671 & 6,674 &, 000 & ,495 & 2,021 \\
\hline & $\mathrm{X} 2$ &,- 118 &, 088 &,- 144 & $-1,349$ &, 182 & ,438 & 2,282 \\
\hline & $\mathrm{X} 3$ &,- 028 &, 142 &,- 017 &,- 197 &, 845 & ,661 & 1,513 \\
\hline & $\mathrm{X} 4$ &,- 005 &, 123 &,- 004 &,- 044 & ,965 & ,489 & 2,046 \\
\hline & $\mathrm{X} 5$ &,- 102 &, 066 &,- 120 & $-1,549$ &, 126 & ,840 & 1,191 \\
\hline & X6 &, 270 &, 118 &, 220 & 2,295 &, 025 & ,541 & 1,848 \\
\hline & X7 &,- 064 &, 065 &,- 079 &,- 981 &, 330 & ,767 & 1,304 \\
\hline & $\mathrm{X} 8$ &, 121 &, 066 &, 173 & 1,832 &, 072 &, 562 & 1,779 \\
\hline
\end{tabular}

a. Dependent Variable: Y

$$
\begin{aligned}
\mathrm{Y}= & 6,557+0,7 \mathrm{X} 1-0,118 \mathrm{X} 2-0,028 \mathrm{X} 3-0,005 \mathrm{X} 4-0,102 \mathrm{X} 5+0,270 \mathrm{X} 6-0,064 \mathrm{X} 7+ \\
& 0,121 \mathrm{X} 8+\mathrm{e}
\end{aligned}
$$

Angka yang dihasilkan dari pengujian tersebut dijelaskan sebagai berikut:

\section{Konstanta (a)}

Nilai konstanta yang diperoleh sebesar 6,557. Hal ini berarti bahwa tanpa adanya pengaruh variabel independen berpengaruh maka nilai variabel dependen akan sebesar 6,557.

\section{Koefisien Regresi $(\beta) \mathbf{X}_{1}$}

Nilai koefisien regresi variabel minat sebesar 0,700.Hal ini menunjukkan bahwa setiap peningkatan satu satuan tingkat minat akan mengakibatkan peningkatan variabel dependen sebesar 0,700 dengan anggapan variabel bebas lainnya tetap.

\section{Koefisien Regresi $(\boldsymbol{\beta}) \mathrm{X}_{2}$}

Nilai koefisien regresi variable potensi diri sebesar -0,118. Hal ini menunjukkan bahwa setiap peningkatan satu satuan tingkat potensi diri akan mengakibatkan penurunan variabel dependen sebesar 0,118 dengan anggapan variabel bebas lainnya tetap.

\section{Koefisien Regresi $(\boldsymbol{\beta}) \mathrm{X}_{3}$}

Nilai koefisien regresi variabel dukungan orang tua sebesar -0,028. Hal ini menunjukkan bahwa setiap peningkatan satu satuan tingkat dukungan orang tua mengakibatkan penurunan variabel dependen sebesar 0,028 dengan anggapan variabel bebas lainnya tetap. 


\section{Koefisien Regresi $(\boldsymbol{\beta}) \mathbf{X}_{\mathbf{4}}$}

Nilai koefisien regresi variabel peluang pekerjaan sebesar -0,005. Hal ini menunjukkan bahwa setiap peningkatan satu satuan tingkat peluang pekerjaan mengakibatkan penurunan variabel dependen sebesar 0,005 dengan anggapan variabel bebas lainnya tetap.

Koefisien Regresi $(\boldsymbol{\beta}) \mathbf{X}_{\mathbf{5}}$

Nilai koefisien regresi variabel biaya sebesar -0,102 .Hal ini menunjukkan bahwa setiap peningkatan satu satuan tingkat biaya akan mengakibatkan penurunan variabel dependen sebesar 0,102 dengan anggapan variabel bebas lainnya tetap.

\section{Koefisien Regresi $(\boldsymbol{\beta}) \mathbf{X}_{6}$}

Nilai koefisien regresi variabel Citra Universitas sebesar 0,270. Hal ini menunjukkan bahwa setiap peningkatan satu satuan tingkat Citra Universitas akan mengakibatkan penurunan variabel dependen sebesar 0,270 dengan anggapan variabel bebas lainnya tetap.

\section{Koefisien Regresi $(\boldsymbol{\beta}) \mathbf{X}_{7}$}

Nilai koefisien regresi variabel keputusan kolektif sebesar -0,064. Hal ini menunjukkan bahwa setiap peningkatan satu satuan tingkat keputusan kolektif akan mengakibatkan penurunan variabel dependen sebesar 0,064 dengan anggapan variabel bebas lainnya tetap.

\section{Koefisien Regresi $(\boldsymbol{\beta}) \mathrm{X}_{\mathbf{8}}$}

Nilai koefisien regresi variabel rekomendasi dari sekolah sebesar $-0,121$. Hal ini menunjukkan bahwa setiap peningkatan satu satuan tingkat rekomendasi dari sekolah akan mengakibatkan peningkatan variabel dependen sebesar 0,121 dengan anggapan variabel bebas lainnya tetap.

\section{d. Uji T}

Pengujian ini bertujuan untuk mengetahui seberapa jauh pengaruh satu variabel independen secara individual dalam menerangkan variasi variabel dependen (Ghozali, 2016).Kriteria penerimaan dan penolakan hipotesis adalah jika $t_{\text {hitung }}>t_{\text {tabel }}$, maka Ha diterima (ada pengaruh signifikan). Jika $t_{\text {hitung }}<\mathrm{t}_{\text {tabel, }}$, maka Ha ditolak(tidak ada pengaruh). Berdasarkan dasar signifikansi, kriterianya adalah jika signifikansi $>0,05$ maka Ha ditolak, jika signifikansi < 0,05 maka Ha diterima (Idris, 2014:54).

\section{Pengujian Hipotesis Pertama $\left(\mathrm{H}_{1}\right)$}

Variabel minat pada tabel 4.15 memiliki nilai thitung $6,674>t_{\text {tabel }} 1,667$ dan nilai sig $(0,000)<\alpha$ $(0,05)$ serta nilai koefisien $\beta$ sebesar 0,700 . Hal ini menunjukkan bahwa variable minat berpengaruh positif terhadap variabel dependen, sehingga dapat disimpulkan bahwa Hipotesis 1 diterima.

\section{Pengujian Hipotesis Kedua $\left(\mathrm{H}_{2}\right)$}

Variabel potensi diri pada tabel 4.15 memiliki nilai $t_{\text {hitung }}-1,349<t_{\text {tabel }} 1,667$ dan nilai sig $(0,182)>\alpha(0,05)$. Hal ini menunjukkan bahwa variabel potensi diri tidak berpengaruh terhadap variabel dependen, sehingga dapat disimpulkan bahwa Hipotesis 2 ditolak.

\section{Pengujian Hipotesis ketiga $\left(\mathrm{H}_{3}\right)$}

Variabel dukungan orang tua pada tabel 4.15 memiliki nilai $t_{\text {hitung }} 0,197<t_{\text {tabel }} 1,669$ dan nilai $\operatorname{sig}(0,845)>\alpha(0,05)$. Hal ini menunjukkan bahwa variabel dukungan orang tua tidak berpengaruh positif terhadap variabel dependen, sehingga dapat disimpulkan bahwa Hipotesis 3 ditolak. 


\section{Pengujian Hipotesis Keempat $\left(\mathrm{H}_{4}\right)$}

Variabel peluang pekerjaan pada tabel 4.15 memiliki nilai $t_{\text {hitung }}-0,044<\mathrm{t}_{\text {tabel }} 1,669$ dan nilai sig $(0,965)>\alpha(0,05)$. Hal ini menunjukkan bahwa variabel peluang pekerjaan tidak berpengaruh terhadap variabel dependen, sehingga dapat disimpulkan bahwa Hipotesis 4 ditolak.

\section{Pengujian Hipotesis Kelima $\left(\mathbf{H}_{5}\right)$}

Variabel biaya pada tabel 4.15 memiliki nilai $t_{\text {hitung }}-1,549<\mathrm{t}_{\text {tabel }} 1,669$ dan nilai sig $(0,126)>$ $\alpha(0,05)$. Hal ini menunjukkan bahwa variabel pengakuan biaya tidak berpengaruh terhadap variabel dependen, sehingga dapat disimpulkan bahwa Hipotesis 5 ditolak.

\section{Pengujian Hipotesis Keenam $\left(\mathrm{H}_{6}\right)$}

Variabel citra universitas pada tabel 4.15 memiliki nilai $t_{\text {hitung }} 2,295>t_{\text {tabel }} 1,69$ dan nilai sig $(0,025)<\alpha(0,05)$. Hal ini menunjukkan bahwa variable citra universitas berpengaruh positif terhadap variabel dependen, sehingga dapat disimpulkan bahwa Hipotesis 6 diterima.

\section{Pengujian Hipotesis Ketujuh $\left(\mathrm{H}_{7}\right)$}

Variabel keputusan kolektifs pada tabel 4.15 memiliki nilai $t_{\text {hitung }}-0,981<t_{\text {tabel }} 1,669$ dan nilai sig $(0,330)>\alpha(0,05)$. Hal ini menunjukkan bahwa variabel keputusan kolektif tidak berpengaruh terhadap variabel dependen, sehingga dapat disimpulkan bahwa Hipotesis 7 ditolak.

\section{Pengujian Hipotesis Ketujuh $\left(\mathrm{H}_{8}\right)$}

Variabel rekomendasidari sekolah pada tabel 4.15 memiliki nilai $t_{\text {hitung }} 1,832<t_{\text {tabel }} 1,669$ dan nilai sig $(0,072)>\alpha(0,05)$. Hal ini menunjukkan bahwa variabel rekomendasi dai sekolah kolektif tidak berpengaruh terhadap variabel dependen, sehingga dapat disimpulkan bahwa Hipotesis 8 ditolak.

\section{Pembahasan}

Pengaruh minat terhadap pengambilan keputusan dalam memilih program studi akuntansi S1 Universitas Negeri Padang

Berdasarkan hasil analisis statistik dalam penelitian terhadap mahasiswa akuntansi angkatan 2019 Fakultas Ekonomi Universitas Negeri Padang dinyatakan bahwa hipotesis 1 diterima. Melaui pengujian regresi berganda, didapatkan minat berpengaruh positif terhadap pengambilan keputusan dalam memilih program studi akuntansi S1.

Minat ditandai dengan asas keinginan dan asas ketertarikan. Hasil yang diperoleh dalam penelitian ini menunjukan minat berpengaruh terhadap pengambilan keputusan dalam memillih program studi akuntansi S1. Artinya, pengambilan keputusan dalam memilih program studi akuntansi S1 Universitas Negeri Padang akan meningkat seiring dengan meningkatnya faktor minat. Hasil penelitian ini sejalan konsisten dengan hasil Sulistyawati, dkk (2017) yang menyatakan minat memiliki pengaruh yang signifikan terhadap pengambilan keputusan dalam memilih program studi akuntansi. Hasil tersebut mampu membuktikan bahwa minat merupakan salah satu faktor penting yang mempengaruhi mahasiswa dalam pengambilan keputusan memilih program studi akuntansi. Mahasiswa akuntansi memilih program studi akuntansi S1 dikarenakan minat yang tinggi terhadap program studi akuntansi. 
Hasil penelitian ini juga seiring dengan penelitian Djamarah dalam Sulistyawati, dkk (2002:132) indikator minat belajar yaitu rasa suka/ senang, pernyataan lebih menyukai, adanya rasa ketertarikan, adanya kesadaran untuk belajar tanpa disuruh, berpartisipasi dalam aktivitas belajar, memberikan perhatian.

\section{Pengaruh potensi diri terhadap pengambilan keputusan dalam memilih program studi akuntansi S1 Universitas Negeri Padang}

Berdasarkan hasil analisis statistik dalam penelitian ini dinyatakan bahwa hipotesis 2 ditolak. Melalui pengujian regresi berganda, didapatkan potensi diri tidak berpengaruh terhadap pengambilan keputusan dalam memilih program studi akuntansi S1 Universitas Negeri Padang. Potensi diri yang semestinya merupakan faktor pengambilan keputusan dalam memilih program studi Akuntansi S1 Universitas Negeri Padang yaitu kemampuan lebih terhadap ilmu akuntansi, pekerjaan lebih lebih mudah diselesaikan dengan adanya potensi diri tersebut, kemampuan analisis mendalam, logika berpikir, bakat yang terpendam dalam akuntansi, tingkat kompetensi yang tinggi namun ternyata tidak berpengaruh terhadap pengambilan keputusan dalam memilih program studi akuntansi S1 Universitas Negeri Padang.

Dalam hal ini menandakan bahwa mahasiswa dalam pengambilan keputusan dalam memilih program studi akuntansi S1 Universitas Negeri Padang tidak mempertimbangkan faktor potensi diri mereka yang akan di hadapi nantinya sehingga menyebabkan ketidaksesuaian dalam proses belajar pada program studi akuntansi di perkuliahan. Hasil penelitian terhadap variabel potensi diri ini sejalan dengan penelitian Hapdi (2016) yang menyatakan bahwa potensi diri tidak berpengaruh terhadap pengambilan keputusan dalam memilih program studi pendidikan ekonomi di universitas Gunadharma. Mendukung penelitian Andini (2015) dalam penelitiannya mengatakan faktor-faktor lain yang mempengaruhi individu dalam menetapkan suatu keputusan lebih besar daripada faktor potensi diri.

\section{Pengaruh dukungan orang tua terhadap pengambilan keputusan dalam memilih program studi akuntansi S1 Universitas Negeri Padang}

Berdasarkan hasil statistik dalam penelitian ini dinyatakan bahwa hipotesis 3 ditolak. Melalui pengujian regresi berganda, didapatkan dukungan orang tua tidak berpengaruh terhadap pengambilan keputusan dalam memilih program studi akuntansi S1 Universitas Negeri Padang. Secara mendalam dapat diketahui dukungan orang tua berupa perhatian orang tua, motivasi orang tua, dan profesi yang ada dalam keluarga tidak berpengaruh terhadap pengambilan keputusan memlih program studi akuntansi S1 Universitas Negeri Padang.

Jika ditinjau dari aspek teoritis maka ini bertentangan dengan teori yang ada. Sebagaimana menurut Dalyono (1997) dalam Marsal (2014) menyatakan bahwa minat dalam menentukan karir timbul karena daya tarik dari luar, salah satunya lingkungan keluarga. Penelitian terdahulu yang sama dengan teori diatas yakni dilakukan oleh Marsal (2014) dalam Gunawan (2017), yang mengatakan bahwa lingkungan keluarga berpengaruh secara signifikan terhadap pengambilan keputusan dalam memilih jurusan akuntansi. Socioeconoic Theori mengatakan bahwa kondisi sosial seperti orang tua, teman, guru atau dosen, status sosial dan kondisi ekonomi seperti, peluang pekerjaan, jumlah gaji, dan sejenisnya berdampak dalam pengambilan keputusan (Venable dalam Dibabe et al, 2015). 
Pengaruh peluang pekerjaan terhadap pengambilan keputusan dalam memilih program studi akuntansi S1 Universitas Negeri Padang

Berdasarkan hasil analisis statistik dalam penelitian ini dinyatakan bahwa hipotesis 4 ditolak. Melalui pengujian regresi berganda, didapatkan peluang pekerjaan tidak berpengaruh terhadap pengambilan keputusan dalam memilih program studi akuntansi S1 Universitas Negeri Padang. Berdasarkan penilitian terdahulu, maka hasil penelitian ini seiring dengan penelitian Ramdani (2013), dimana hasil penelitian menunjukan bahwa variabel peluang kerja tidak berpengaruh terhadap pemilihan karir mahasiswa akuntansi.

\section{Pengaruh Biaya tehadap pengambilan keputusan dalam memilih program studi akuntansi} S1 Universitas Negeri Padang

Berdasarkan hasil analisis statistik dalam penelitian ini dinyatakan bahwa hipotesis 5 ditolak. Melalui pengujian regresi berganda, didapatkan biaya tidak berpengaruh terhadap pengambilan keputusan dalam memilih program studi akuntansi S1 Universitas Negeri Padang. Biaya ditandai dengan adanya sebagai masalah bagi mahasiswa dalam menempuh pendidikan seperti biaya kuliah yang tinggi sehingga mahasiswa tidak menginginkan program studi akuntansi S1 Universitas Negeri Padang sebagai pilihan.

Jika dilihat dari tingkat capaian responden untuk variabel biaya sudah tergolong baik, dengan rerata sebesar 248,5. Dengan ini dapat dikatakan bahwa keadaan biaya mahasiswa akuntansi yang menjadi sampel dalam penelitian ini sudah dikatakan baik. Hal ini membuktikan bahwa biaya tidak menjadi masalah mahasiswa dalam memilih program studi akuntansi S1. Sejalan dengan penelitian Hanum (2017) menyatakan bahwa Kondisi finansial Mahasiswa sudah dalam kategori baik sehingga tidak berpengaruh dalam pengambilan keputusan memilih program studi kedokteran universitas Brawijaya.

Pengaruh citra universitas terhadap pengambilan keputusan dalam memilih program studi akuntansi S1 Universitas Negeri Padang

Berdasarkan hasil analisis statistik dalam penelitian ini dinyatakan bahwa hipotesis 6 diterima. Melalui pengujian regresi berganda, didapatkan lingkungan keluarga berpengaruh positif terhadap pemilihan pengambilan keputusan dalam memilih program studi akuntansi S1 Universitas Negeri Padang. Secara mendalam dapat diketahui bahwa citra universitas merupakan branding atau nama baik suatu produk yang dapat menarik perhatian konsumen untuk membeli suatu produk tersebut.

Berdasarkan penelitian terdahulu, maka hasil penelitian ini sejalan dengan penelitian Kusuma (2016) dalam Wibowo (2009), dimana reputasi juga sering didefenisikan sebagai keunggulan kompetitif terpenting yang dimiliki oleh perusahaan. Jika dilihat dari tingkat capaian responden untuk citra universitas sudah tergolong sangat baik, dengan rerata sebesar 289,7. Dengan ini dapat dikatakan bahwa citra universitas pada mahasiswa akuntansi S1 angkatan 2019 yang menjadi sampel dalam penelitian ini sudah dikatakan sangat baik.

\section{Pengaruh keputusan kolektif terhadap pengambilan keputusan dalam memilih program} studi akuntansi S1 Universitas Negeri Padang

Berdasarkan hasil analisis statistik dalam penelitian ini dinyatakan bahwa hipotesis 7 ditolak. Melalui pengujian regresi berganda, keputusan kolektif tidak berpengaruh terhadap pengambilan keputusan dalam memilih program studi akuntansi S1 Universitas Negeri Padang. Keputusan kolektif ditandai dengan adanya musyawarah calon mahasiswa akuntansi S1 Universitas Negeri 
Padang atau berupa saran dan pendapat orang lain yang diterima sebagai bahan pertimbangan dalam pengambilan keputusan.

Dalam beberapa contoh keputusan kolektif juga tidak berpengaruh terhadap pengambilan keputusan karena adanya ego dan faktor dari dalam diri yang mempengaruhi keputusan calon mahasiswa. Sejalan dengan penelitian Riandini (2018) Keputusan kolektif hanya mempengaruhi mahasiswa sebesar 56,65 dengan kategori kurang baik yang mana artinya keputusan kolektif tidak berepengaruh signifikan terhadap Mahasiswa yang memillih jurusan Matematika di Universitas Riau.

\section{Pengaruh rekomendasi sekolah terhadap pengambilan keputusan dalam memilih program studi akuntansi S1 Universitas Negeri Padang}

Berdasarkan hasil statistik dalam penelitian ini dinyatakan bahwa hipotesis 8 ditolak. Melalui pengujian regresi berganda, didapatkan rekomendasi sekolah tidak berpengaruh terhadap pengambilan keputusan dalam memilih program studi akuntansi S1 Universitas Negeri Padang. Rekomendasi Sekolah ditandai dengan adanya sekolah memberikan penawaran dalam memilih jurusan hal ini sangat wajar mengingat sekolah merupakan tempat belajar calon mahasiswa.

Dalam hal ini menandakan bahwa mahasiswa dalam pengambilan keputusan dalam memilih program studi akuntansi S1 Universitas Negeri Padang tidak mempertimbangkan faktor rekomendasi sekolah yang akan mereka hadapi nantinya sehingga menyebabkan ketidaksesuaian. Sejalan dengan penelitian Novia (2017) Faktor sekolah tidak berpengaruh terhadap pemilihan jurusan perhotelan di Universitas Negeri Padang.

\section{KESIMPULAN KETERBATASAN SARAN Kesimpulan}

Penelitian ini dilakukan untuk mengetahui apakah minat, potensi diri, dukungan orang tua, peluang pekerjaan, biaya, citra universitas, keputusan kolektif dan rekomendasi dari sekolah berpengaruh terhadap pengambilan keputusan dalam memilih program studi akuntansi S1 Universitas Negeri Padang Berdasarkan hasil analisa dari penelitian ini dapat disimpulkan beberapa informasi sebagai berikut:

1. Minat berpengaruh positif terhadap pengambilan keputusan dalam memilih program studi akuntansi S1 Universitas Negeri Padang

2. Potensi diri tidak berpengaruh terhadap pengambilan keputusan dalam memilih program studi akuntansi S1 Universitas Negeri Padang

3. Dukungan Orang Tua tidak berpngaruh terhadap pengambilan keputusan dalam memilih program studi akuntansi S1 Universitas Negeri Padang

4. Peluang pekerjaan tidak berpengaruh terhadap pengambilan keputusan dalam memilih program studi akuntansi S1 Universitas Negeri Padang

5. Biaya tidak berpengaruh terhadap pengambilan keputusan dalam memilih program studi akuntansi S1 Universitas Negeri Padang

6. Citra universitas berpengaruh positif terhadap pengambilan keputusan dalam memilih program studi akuntansi S1 Universitas Negeri Padang

7. Keputusan kolektif tidak berpengaruh terhadap $p$ pengambilan keputusan dalam memilih program studi akuntansi S1 Universitas Negeri Padang

8. Rekomendasi Sekolah tidak berpengaruh terhadap pengambilan keputusan dalam memilih program studi akuntansi S1 Universitas Negeri Padang 


\section{Keterbatasan}

Meskipun peneliti telah berusaha merancang dan mengembangkan penelitian sedemikian rupa, namun masih terdapat beberapa keterbatasan dalam penelitian ini yang masih perlu revisi penelitian selanjutnya, antara lain:

1. Adanya wabah pendemi global yaitu virus corona atau Covid 19 yang menghalangi peneliti dalam menyebar data kuesioner yang awalnya menggunakan teknik Total Sampling agar lebih akurat namun hanya menggunakan Random Sampling namun sudah sesuai dengan teori yang ada dan telah mewakili jawaban dari keseluruhan sampel.

2. Kurangnya kesadaran responden dalam mengisi kuesioner karena ada data yang tidak kembali pada peneliti

\section{Saran}

Berdasarkan hasil penelitian yang telah dilakukan oleh peneliti, penelitian ini masih ada kekurangan, sehingga banyak yang perlu diperbaiki dan diperhatikan lagi untuk peneliti selanjutnya.

1.Penelitian selanjutya diharapkan lebih teliti dalam menetapkan faktor-faktor yang mempengaruhi pengambilan keputusan dalam memilih program studi akuntansi S1 karena pada setiap Universitas sangat memungkinkan adanya perbedaan faktor-faktor.

2. Penelitian selanjutnya disarankan untuk memperluas cakupan wilayah seperti kota atau provinsi.

\section{DAFTAR PUSTAKA}

Ahmadi, Abu. (2009). Psikologi Sosial. Jakarta : Rineka Cipta

Akreditasi Universitas dan Program Studi Akuntansi program sarjana Universitas Negeri Padang. http://fe.unp.ac.id/page/sertifikat-akreditasi (Diakses pada: 21 Oktober 2019, pukul 21.36 WIB)

Andini, Syifa. (2015). Analisis Pengaruh Lingkungan Keluarga, Minat, dan Potensi Diri Dalam Pengambilan Keputusan Mahasiswa Memilih Jurusan Menejemen di Universitas Islam Negeri Bandung. Skripsi. Universitas Islam Negeri Bandung.

Budi, Isman. (2015). Definisi dan Dasar Pengambilan Keputusan. http://ismaan.wordpress.com/2015/05/19/definisi-dandasar-pengambilankeputusan/( Diakses pada: 10 Oktober 2019, pukul 00.17 WIB)

Dalyono. (1997). Psikologi Pendidikan. Semarang : Rineka Cipta

Dasar-dasar pengambilan keputusan. https://www.ilmu-ekonomi-id.com/2018/09/dasar-dasarpengambilan-keputusan.html( Diakses pada: 10 Oktober 2019, pukul 02.18 WIB)

Erlita. (2012). Analisis faktor atas pengambilan keputusan mahasiswa untuk mengambil jurusan akuntansi di STIE Perbanas Surabaya. Skripsi. Sekolah Tinggi Ilmu Ekonomi Perbanas.

Fandilon, Sutan. (2019). Faktor-Faktor yang Mempengaruhi Mahasiswa Akuntansi dalam Pemilihan Karir menjadi Auditor Pemerintah dan Swasta. Skripsi. Universitas Negeri Padang

Ghozali, Imam. (2005). Aplikasi Analisis Multivariate Dengan Program SPSS. Semarang: Badan Penerbit Universitas Diponegoro

Hanum, Adara. (2017). Analisis Pengaruh Profesi Orang Tua, Finansial, Lingkungan, Potensi Diri Pada Mahasiswa Terhadap Pengambilan Keputusan Memilih Program Studi 
Kedokteran Universitas Brawijaya. Skripsi. Universitas Brawijaya

Hapdi. (2016). Faktor-Faktor Yang Mempengaruhi Mahasiswa dalam Pengambilan Keputusan Memilih Program Studi Pendidikan Ekonomi di Univesitas Gunadharma. Skripsi. Universitas Gunadharma

Harahap. (2015). Analisis faktor-faktor yang mempengaruhi keputusan mahasiswa dalam memilih jurusan akuntansi sebagai tempat kuliah di universitas di kota pekanbaru. Skripsi. Universitas Riau.

Hayurika dan Arief. (2015). Analisis faktor-faktor yang mempengaruhi minat siswa dalam pengambilan keputusan memilih jurusan akuntansi kelas X di SMK N 1 Demak. Jurnal Pendidikan Ekonomi Dinamika Pendidikan. Vol. X, No.1 Juni 2015 ( Hal 88-103)

Hevi, Hendri John. (2013). Pengaruh Struktur Organisasi Dan Sistem Informasi Manajemen Terhadap Pengambilan Keputusan Managemen(Survey pada 10 Kantor Pelayanan Pajak di Kanwil Jawa Barat I). Jurusan Akuntansi Universitas Komputer Indonesia

Kusuma, Lenny. (2016). Faktor-faktor yang mempengaruhi pengambilan keputusan mahasiswa dalam memilih program studi pendidikan akuntansi di universitas negeri semarang. Fakultas Ekonomi Pendidikan Akuntansi UNNES

Mehboob, Farhan, et al. (2012). Factors Influencing Students Enrollment Decisions in Selection of Higher Education Institutions (HEI,,S). Insitute of Interdisciplinary Business Research. Vol. 4, No. 5

Mulyono. (2010). Konsep Pembiayaan Pendidikan. Yogjakarta : Ar Ruzz Media

Novia, Rama. (2017). Faktor-Faktor yang Mempengaruhi Mahasiswa Dalam Pengambilan Keputusan Memilih Jurusan Perhotelan Universitas Negeri Padang.

Peraturan Menteri Riset, Teknologi, dan Pendidikan Tinggi (Permenristekdikti) UndangUndang Nomor 44 Tahun 2015 Tentang Standar Nasional Pendidikan Tinggi. Jakarta:

Diperbanyak oleh PT Armas Duta Jaya.

Pengertian Program Studi menurut Institusi Teknologi DEL. https://www.del.ac.id/?page id=109. ( Diakses pada: 09 Oktober 2019, pukul 23.42 WIB)

Profil Universitas Negeri Padang. https://infounp.or.id/profil-universitas-negeripadang/( Diakses pada: 08 Oktober 2019, pukul 01.29 WIB)

Profil Universitas Negeri Padang. https://id.wikipedia.org/wiki/Universitas Negeri Padang. ( Diakses pada: 08 Oktober 2019, pukul 01.36 WIB)

Ramdani, Rahmat Fajar. (2013). Analisis Faktor-Faktor yang Mempengaruhi Penilian Karir Mahasiswa Akuntansi. Universitas Diponegoro. Semarang.

Riandini, Natasha. (2018). Analisis Faktor yang Mempengaruhi Mahasiswa dalam Mengambil Keputusan Memilih Jurusan Matematika Universitas Riau. Skirpsi. Universitas Riau

Sekaran, Uma. (2006). "Research Methods For Business. Metodologi Penelitian Untuk Bisnis Edisi Empat, Buku Satu". Jakarta: Salemba Empat.

Sovia. (2007). Analisis Faktor yang mempengaruhi keputusan peminat untuk memilih jurusan akuntansi universitas sanata dharma Yogyakarta. Skripsi, Universitas Sanat Dharma Yogyakarta.

Suartana, I Wayan. (2010). “ Akuntansi Keperilakuan Teori dan Implementasi”. Yogyakarta :Penerbit Andi

Sugiyono. (2008). Metode Penelitian Pendidikan Pendekatan Kuantitatif, Kualitatif dan R\&D. Bandung: Alfabeta.

Sugiyono. (1999). Metode Penelitan Bisnis, Cetakan Ke-6, Bandung: CV. Alfa Beta. 
Sulistyawati, Herawati, dan Julianto. (2017). Pengaruh minat, potensi diri, dukungan orang tua dan kesempatan kerja, terhadap keputusan mahasiswa memilih jurusan akuntansi program S1 Universitas Pendidikan Ganesha. E-Journal S1 Ak Universitas Pendidikan Ganesha Jurusan Akuntansi S1, Vol. 8, No.2, Tahun 2017

Teori-Teori Pengambilan Keputusan (Decision Making)

http://mulyono.staff.uns.ac.id/2009/06/08/teori-pengambilan-keputusan-theory-of-

decision-making/.( Diakses pada: 10 Oktober 2019, pukul 02.18 WIB)

Undang-Undang Republik Indonesia No.12 Tahun 2012 tentang Pendidikan Tinggi 1990. Jakarta: Diperbanyak oleh PT Armas Duta Jaya.

Undang-undang Republik Indonesia Nomor 20 Tahun 2003 tentang Sistem Pendidikan Nasional. 1990. Jakarta: Diperbanyak oleh PT Armas Duta Jaya.

Wijayanti. (2003). "Faktor-Faktor yang Mempengaruhi Pemilihan Karir Mahasiswa Akuntansi di Yogyakarta", Jurnal Riset Akuntansi Indonesia, Vol. 3, No.2, Juli, Hal. 13 - 26.

Zulaikhah, Nurhimah. (2014). Hubungan antara orang tua dan orientasi karir dengan pengambilan keputusan studi lanjut. Tesis. Surakarta : Universitas Muhammadiyah Surakarta 